\title{
ЛИНГВИСТИКА ПОВСЕДНЕВНОСТИ
}

DOI $10.37386 / 2305-4077-2020-3-112-125$

\author{
Н. Б. Лебедева
}

Кемеровский государственный университет

Т. Г. Рабенко ${ }^{2}$

Кемеровский государственный университет

\section{ТЕКСТЫ ЕСТЕСТВЕННОЙ ПИСЬМЕННОЙ РЕЧИ КАК ПРОЯВЛЕНИЕ ЦЕННОСТНЫХ ДОМИНАНТ РЯДОВОГО НОСИТЕЛЯ ЯЗЫКА}

\author{
(НА МАТЕРИАЛЕ РОДИТЕЛЬСКИХ ПИСЕМ) ${ }^{3}$
}

В статье осуществляется апробация идеи возможного описания текстов естественной письменной речи с позиции аксиологической филологии. Обосновывается положение о значительной проявленности личностного начала в определенных жанрах естественной письменной речи, тексты которой не подвергаются редактированию и цензурированию, что является одним из специфических особенностей данного вида речевой деятельности. Реализуемый в работе аксиологический подход к рассмотрению текстов естественной письменной речевой деятельности составляет один из аспектов изучения естественной письменной речи в той его части, которая направлена на описание личностного начала в различных жанровых формах этого вида речи. В качестве материала исследования взяты родительские письма, где личностное начало воплощается особенно явственно. В результате аксиологического анализа писем, осуществляемого с опорой на метод ключевых слов, обнаруживаются терминальные (любовь, здоровье, благополучие) и инструментальные (труд, образованность, рачительность, самодисциплина) ценности, формирующие аксиосферу личности родителя.

Ключевые слова: естественная письменная речь, жанр, личностное начало автора, ценностная доминанта, родительское письмо.

\section{N. B. Lebedeva \\ Kemerovo state University \\ T. G. Rabenko \\ Kemerovo state university}

\footnotetext{
1 Наталья Борисовна Лебедева, доктор филологических наук, профессор, профессор кафедры стилистики и риторики Кемеровского государственного университета (Кемерово).

2 Татьяна Геннадьевна Рабенко, доктор филологических наук, доцент, профессор кафедры стилистики и риторики Кемеровского государственного университета (Кемерово).

3 Исследование выполнено при финансовой поддержке РФФИ в рамках проекта «Концептуально-ценностный анализ эпистолярного и мемуарного наследия жителей Кузбасса» (№ 20-412-420005 p_a).
} 


\section{TEXTS OF NATURAL WRITTEN SPEECH AS}

\section{A MANIFESTATION OF THE VALUE DOMINANTS OF AN ORDINARY NATIVE SPEAKER}

\section{(BASED ON THE MATERIAL OF PARENTS ' LETTERS)}

The article tests the idea of a possible description of natural written speech texts from the position of axiological Philology. Statement of significant manifestation of personality in particular genres of natural written language, texts not subject to editing, and redaction, which is one of the specific features of this type of speech activity. The axiological approach to the consideration of texts of natural written speech activity implemented in this work is one of the aspects of the study of natural written speech in the part that is aimed at describing the personal beginning in various genre forms of this type of speech. The material of the research is taken from parents ' letters, where the personal principle is especially clearly embodied. As a result of axiological analysis of letters, based on the method of keywords, we find terminal (love, health, well-being) and instrumental (work, education, diligence, self-discipline) values that form the axiosphere of the parent's personality.

Key words: natural written speech, genre, author's personal beginning, value dominant, parent letter.

\section{І. Введение}

Настоящее исследование выполнено в контексте теории естественной письменной речи (далее ЕПР), связанной с изучением речевой деятельности (и ее результата - текстов), которая обладает письменной формой, спонтанностью и непрофессиональностью исполнения [Лебедева, 2006, с. 295]. Став в начале 2000-х гг. основным объектом изучения Барнаульско-Кемеровской лингвистической школы, письменно-речевая деятельность рядового носителя языка обнаруживает несколько аспектов изучения: речежанроведческий [Крючкина, 2016; Лебедева, 2011; Рабенко, 2018b, 2020], лингводидактический [Голев, 2003], лингвоперсонологический [Лебедева, 2013] и др. Результаты многочисленных исследований, отраженных в работах различной научной квалификации: монографий [Лебедева, 2011; 2013; Рабенко, 2018а и др.], диссертаций [Зырянова, 2009; Тюкаева, 2005; Рабенко, 2018а; Сухотерина, 2007 и др.], статей [Крючкина, 2016; Лебедева, 2006; Рабенко, 2020 и др.],--свидетельствуют о том, что в настоящее время накоплен определенный теоретический и эмпирический материал, способствующий некоторому осознанию природы ЕПР, еe сущностных характеристик. Однако эвристические возможности описания ЕПР еще не исчерпаны. Представление о ЕПР как естественной письменноречевой деятельности, обнаруживающей выраженное авторское начало и не предполагающей участия в создании текстов каких-либо других субъектов (редакторов, корректоров, цензоров), легло в основу научной гипотезы настоящей работы: естественные письменные репрезентации рядового носителя языка, в осуществлении которых человек не направлен на решение презентационных 
задач и которые не предполагают некой сторонней оценивающей позиции, могут послужить источником выявления особенностей авторской личности, создающей жанровооформленные тексты ЕПР. При этом различные жанры ЕПР обладают разной степенью проявленности авторского начала и, как следствие, различной дозированностью в реализации аксиологической составляющей речепроявления.

Актуальность настоящего исследования определяется его вписанностью в теорию ЕПР в той ее части, которая связана с выявлением специфических свойств ЕПР в ее жанровом преломлении. В данной работе поставлена цель-описание личностного начала в текстах ЕПР и в связи с этим оценивание письменноречевой деятельности рядового носителя языка как одного из возможных источников обнаружения ценностных ориентиров современного общества. Известно, что внутренний план бытия личности для стороннего исследователя может быть проявлен посредством различных знаковых репрезентаций. Один из таковых путей, ведущих к познанию внутреннего плана существования личности, сопрягается с изучением естественных письменных репрезентаций человека, выявлении жанров ЕПР, в которых аксиосфера личности наиболее проявлена. Получены первые результаты аксиологического «замера» жанров ЕПР: народных мемуаров [Лебедева, 2019] и личных дневников [Рабенко, 2019]. Научная новизна предпринимаемого исследования обусловлена следующими результатами. Тексты ЕПР рассмотрены с позиции аксиологической филологии. С учетом онтологической природы ЕПР как письменно-речевой деятельности рядового носителя языка, где человек, находясь вне позиции некоего внешнего оценивания (со стороны редактора, корректора и пр.), естественен в своем речетворчестве. Тексты ЕПР привлечены как возможный источник воссоздания ценностных предпочтений личности. Посредством привлечения семейного эпистолярия оцениваются эвристические возможности текстов ЕПР как основы аксиологического анализа.

\section{II. Фактологическая база и методы исследования}

Фактологическую базу исследования составили архивные материалы Лаборатории ЕПР Кемеровского государственного университета (всего более 200 родительских писем). Адресатом писем является девушка - студентка, а впоследствии преподаватель одного из сибирских вузов. Адресанты - родители: отец - директор завода, мать - маркшейдер, впоследствии пенсионеры. В семье четверо детей (адресат - старшая дочь). Датировка писем - 70-90-е гг. XX в.

В качестве основного метода исследования выступает метод ключевых слов. Под ключевым словом понимается «такое опорное слово, которое аккумулирует основной смысл текста, является его семантическим и композиционным центром» [Тороп, 1995, с. 104]. Ключевые слова являются наиболее значимыми и существенными для понимания содержания текста. Они выступают в роли доминантных элементов, при изменении которых меняется смысл текста. По мнению В. Д. Черняк, «ключевое слово - толчок к обогащению мысли»; «всплыв на поверхность сознания, [оно - прим. авт.] начинает вытягивать системнорелевантные для него < ..> ассоциаты и связи» [Черняк, 1990, с. 29], осуществляя 114 
тем самым процесс понимания. В результате, строясь по системе встречного порождения, совокупность ключевых слов в качестве семантического ядра образует «текст-примитив» [Сахарный, 1988, с. 37], максимально компрессированный текст, легко воспроизводимый по четким структурным связям или «смысловым вехам» [Новиков, 1983, с. 114], по которым происходит ориентировка в содержании текста ${ }^{4}$.

\section{III. Тексты ЕПР как отражение аксиологических ценностей рядового носителя языка}

Устойчивое внимание к естественной письменной речевой деятельности рядового носителя языка, продуктам этой деятельности обусловливает внимание к семейной коммуникации в ее различных жанровых проявлениях. Первоначально вовлекаемая в научное исследование как часть разноаспектного описания устноразговорного повседневного общения [Русская разговорная речь, 1973; Чайковский, 1982] семейная коммуникация рассматривается теперь как самостоятельный научный объект [Байкулова 2006; Занадворнова, 2001; Кабанова, 2004]. С учетом полученных результатов становится очевидным, что вовлечение в зону научных поисков устной, а в дальнейшем и письменной формы семейной коммуникации обладает значительными эвристическими возможностями в плане формирования теории ЕПР и существенно обогащает научное представление о семейном общении как специфическом виде речевой коммуникации.

Будучи «средоточием всей $<\ldots>$ нравственной и хозяйственной деятельности [человека - прим. авт.], смыслом существования, опорой <..> миропорядка» [Белов, 2013, с. 183], семья является тем местом, где закладываются культурные и поведенческие стереотипы, формируются ценностно-смысловые ориентации субъекта. Формирование личности начинается именно в семье: семейные ценности, усваиваемые «человеком постепенно, с нарастанием их глубины и серьезности» [Белов, 2013, с. 183], прививают нужные навыки для гармоничного развития целостной натуры.

В семейном речевом общении представлен широкий спектр коммуникативных ситуаций: бытовые диалоги, разговоры по душам, нравоучительные беседы с детьми, наставления и пр. В этих ритуализованных микрообрядах поддерживаются ценности конкретной семьи и русского семейного общения в целом. Естественная письменная речь в ее эпистолярном воплощении дает возможность представить бытовую повседневность как место прямой коммуникации, позволяющей зафиксировать специфические способы переживания опыта, характерного для родителей, выявить особенности родительской аксиосферы. Письма родителей, посланные дочери и затем бережно хранимые ею на протяжении многих лет, наряду с информацией, касающейся каких-либо житейских вопросов (покупки нового пальто, планирование отпуска, дачных забот и пр.), содержат сведения (реализуемые открыто или косвенным образом), обнаруживающие жизненные приоритеты отца и матери, которые они транслируют своим детям. Эта система ценностей доминирует в сознании авторов писем и определяет их отношение к окружающему

4 Иные значения термина «ключевые слова» см.: [Сковородников, 2003, с. 153-157]. 
миру, Другому, самому себе. Аксиологическое исследование родительских писем дает основание судить о ценностных координатах и результатах оценочной деятельности субъектов, отражаемой в письменной речи; позволяет выделить аксиологические доминанты их ценностной картины мира.

Психологическое понятие «доминанта», веденное психофизиологом А.А. Ухтомским, обозначает временно господствующую рефлекторную систему, которая обусловливает работу нервных центров организма в определенный момент времени, определяя тем самым направленность поведения и, что важно, влияя на характер восприятия мира [Ухтомский, 2002, с. 48]. Доминанта обусловливает «общий колорит, под которым рисуются мир и люди». Воздействуя на характер восприятия мира, она обладает свойством «отбирать в нем преимущественно такое познавательное содержание, которое способствовало бы ее подкреплению» [Ухтомский, 2002, с. 49]. Доминанта проявляется достаточно отчетливо в речевой деятельности человека. Обнаружение доминант в эпистолярных текстах осуществляется с опорой на выявление ключевых элементов текста (их комбинаций), которые включают основной смысл определенной части текста и в итоге моделируют оценочно-рефлексирующий компонент в структуре эпистолярного текста [Вознесенская, 2006, с. 42]. Последний отражает результаты восприятия, осмысления автором тех или иных событий и эмоциональной реакции на них. Выделяемый наряду с информативным (представляющим некоторое событие) и фатическим (реализованным посредством этикетных и вводноконтактных формул [Кабанова, 2004, с. 6]) компонентами, рефлексивный компонент эпистолярного текста отражает событие, пропущенное сквозь сознание автора и ставшее результатом авторского осмысления.

Членение структуры эпистолярного текста на информативно-фатический и рефлексивный компоненты коррелирует с высказанным Н.Д.Арутюновой тезисом о различении понятий «событие» и «факт»: «ход вещей создается событиями; события, преломляясь в гранях человеческого сознания, оборачиваются фактами» [Арутюнова, 1999, с. 517]. Ценностные доминанты, актуализированные в эпистолярном дискурсе, реализуются в информативно-фатическом компоненте в виде избираемого для привнесения в текст письма субъективно значимого события, номинирующего «процессы, действия, условия, ситуации, изменения, положения дел» [Арутюнова, 1999, с. 407]. Однако ценностные приоритеты автора отражаются преимущественно в рефлексивной части эпистолярного текста, где событие становится объектом восприятия и оценки пишущего. При этом рефлексивный компонент в разных эпистолярных текстах характеризуется разной степенью развернутости и полноты речевых средств: от единичных употреблений до значительных по объему фрагментов, где воспроизведение состояния сознания становится самоцелью.

Актуализируя тезис Милтона Рокича о существовании оппозиции терминальных и инструментальных ценностей [Rokeach, 1967, с. 31], обозначим семейные ценности, формирующие ценностно-смысловую сферу личностей родителей. 


\section{Терминальные ценности, относящиеся к жизненным целям.}

1. Любовь как ценность. Любовь (родительская) как ценность становится центром эпистолярного повествования, она организует все смысловое пространство родительских писем. Как главная семейная ценность любовь проявляется в нежности по отношению к любимой дочери, ее поддержке (психологической и материальной), стремлении быть в курсе всех событий ее жизни и при необходимости дать нужный совет; в словах родителей чувствуется уверенность в способностях дочери, в успешности ее учебной деятельности, эта уверенность также выполняет функцию поддержки: «Мы соскучились по тебе. Ждали что ты приедешь. Дорогая моя, будь здорова» (мать) $)^{5}$; «Желаю, милая, окончить блестяще первый курс» (мать); «Не отчаивайся, ничего не бойся. Будь здорова, желаем всего наилучшего» (отеи); «Твори, дерзай. От нас с папой ты всегда найдешь поддержку» (мать).

Родительская любовь не выражается в текстовом пространстве прямо, посредством слова «люблю». Чаще всего она проявляется опосредованно, через использование обращений: милая (моя, наша), дорогая (моя, наша) Наташенька, моя родная, дорогая моя доченька и т. п. Такое речевое поведение соответствует особенностям русского менталитета: любовь в русской культуре больше действенная, чем словесная [Формановская, 1989, с. 66].

Необходимость заботы о своих родных как проявление семейной любви транслируется и на поведение адресата: родители пишут об обязанности адресата как старшей среди детей опекать своих младших сестер и брата, оказывать им необходимую моральную поддержку, а в некоторых случаях проявлять назидательность: Наташа, знаем, что тебе некогда, но не бросай ее [младмую сестру - прим. авт.], где подбодри, где как [...] бросать нельзя подбадривать надо (мать).

Мотив любви получает эпистолярное воплощение и в любви романтической как одной из необходимых составляющих гармоничного существования молодой девушки. На обеспокоенность взрослой дочери по поводу отсутствия серьезных отношений с молодыми людьми мать пишет: «[...]брось эти мрачные мысли вот защитисся и выйдешь замуж».

2. Чувство дружбы. Дружба как духовное общение, взаимная личная заинтересованность людей, стремление выказывать эмоциональную поддержку и добровольно помогать в случае нужды составляет одну из ценностей данной семьи. Ключевые слова, актуализирующие данную доминанту,- это лексемы (и их сочетания), интегрированные семой 'дружба': «дружный», «подруга», «дружить», «дружеские отношения», «дружеская поддержка» и др. Актуализируя идею дружбы, мать пишет своим дочерям (несколько писем к обозначенному выше адресату содержат обращения к старшей и младшей дочери, последняя впоследствии тоже становится студенткой) о необходимости дружеской (сестринской) поддержки, взаимопомощи: «Девочки это хорошо что вы вместе и дружны. Помогайте советом делом и поддерживайте друг другу»; "Девочки, дорогие мои, будьте дружны, выдержаны, помогайте друг другу и делом, и советом»; «[...] дорожите, любите друг друга».

5 Здесь и далее сохраняется авторская орфография и пунктуация. Курсив здесь и далее наш. - Н.Л.; Т.Р. 
Проявление любви и дружбы в этой семье имеет одну особенность: родители не занимают позицию «над» детьми, позицию контролера и «оценивателя», упрекающего судьи. В текстах родительских писем отсутствуют слова и выражения, содержащие упреки, угрозы, жалобы на финансовые и эмоциональные затраты. Наоборот, письма проникнуты выражением единства, сопереживания, к чему призывают и дочерей. Чувство дружбы, восхищения и уважения проявляется и в отношениях между родителями, что выражается в словах матери о муже: «Его терпению и силе воли я удивляюсь и восхищаюсь».

3. Здоровье (физическое) как ценность. Здоровье как абсолютная и непреходящая жизненная ценность занимает одну из верхних ступеней в иерархической лестнице ценностей данной семьи (безусловно, всего человечества). Здоровье является тем ресурсом, от степени обладания которым зависит уровень удовлетворения всех потребностей человека. Данная доминанта вербализуется посредством лексем (и их сочетаний), объединенных семой ‘здоровье': «здоровье», «здоровый», «крепкое здоровье» и др. Среди них частотны благопожелания «будь здорова», «не болей», «здоровья тебе», размещаемые преимущественно в заключительной части письма. Выступая в качестве основы активной, творческой и полноценной жизни, здоровье способствует гармоничному существованию, определяет смысл и счастье человеческого бытия: «У тебя последний год учебы. Начнется творческая самостоятельная, дай бог, счастливая жизнь. Поэтому нужно быть сильной и в знаниях и здоровья иметь и тогда всё по плечу» (мать).

Выделяются содержательные особенности составляющих здорового образа жизни:

1) искоренение вредных привычек: «Сама [сын-прим. авт.] курит, как старик, одну папиросу бросает, другую начинает. Вы знаете какая я противница этого курения, папка гробил свое здоровье и этот тоже, ничего хорочего нет»; «Саша бросил курить, я рада»;

2) рациональное питание и правильный образ жизни: «Мы не болеем, лечимся, закаляемся по системе Иванова, по субботам голодаем» (отеи). «Натама, я поправляюсь, живот растет, аппетит большой. Ть голодаешь? Надо после 6-7 часов вечера не есть. Возьмись за это, я умоляю тебя. Я хочу, чтоб у вас было всё, как по Чехову» (мать);

3) оптимальный двигательный режим, систематическое выполнение физических упражнений: «Хожу по утрам на зарядку свою в парк» (мать);

4) закаливание: «Папа каждое утро обливается. Его терпению и силе воли я удивляюсь и восхищаюсь» (мать).

4. Благополучие как ценность. Благополучие как ценность содержательно амбивалентно, поскольку эта ценностная доминанта включает понятие материального благополучия (материальной обеспеченности, достатка) и понятие духовного благополучия, сопрягаемого с ощущением гармоничного существования и удовлетворенностью жизнью. Задействованный в исследовании эпистолярий фиксирует представление советского человека о материальном благополучии, 
воплощением которого являются атрибуты материально благополучной советской семьи (мебельный гарнитур, дорогой ковер, меховая шапка и пр.): «[...] живуm хорошо, имеют обстановку, гарнитур, хорошие дачи» [отец о родственниках-прим. авт.]; «Мы решили с мамой-бабой сделать Жене [внучке-прим. авт.] к 20-летию хороший подарок. Mы [...] присмотрели неплохой ковер за 4.000».

Инструментальные ценности, определяющие некие стандарты поведения или некие способы достижения жизненных целей.

1. Труд как ценность (прилежание в учебе). В представлении родителей, трудолюбие является одним из самых важных и показательных качеств человека, сам труд считается необходимым условием полноценного человеческого существования. Мотив труда в его аксиологическом аспекте широко представлен в эпистолярном тексте и воплощается посредством лексем (и их сочетаний), объединенных семой 'труд': «трудиться», «трудовая [жизнь - прим. авт.]», «работа», «работать», «работник» и др. Применительно к жизненному этапу, на котором находится дочьстудентка, идея труда воплощается преимущественно как плодотворная учебная деятельность: «В молодые годы нужно учиться [...] Чаще пиши письма нам, подругам, товарищам. Это приучит тебя излагать свои мысли на бумаге, а это важно» (отец); "Как у тебя дела, учеба, не запускай, пожалуйста [...] надо много заниматься» (мать); «Главное - кончить хорочо курс» (мать).

Представление о достойном труде воплощается в родительских письмах и посредством повествования родителей о собственных трудовых успехах: «За III квартал нашему заводу присудили премию по министерству. Поздравил нас сам министр. Премия заводу 1700 рублей» (отеи); «Работать приходится много, ходить и уставать стала сильно. Работать хоть и трудно, нужно» (мать).

Исследуемый материал обнаруживает отношение к труду как ценности, характерное для человека, сформированного социалистической системой, где труд составляет «основную сферу жизнедеятельности человека, проявление его социальной сущности» [Зиятдинов, 2004, с. 15]. Среди духовных стимулов трудовой деятельности интерес к труду как таковому, удовлетворение, получаемое от самого процесса трудовой деятельности, в которой реализуются творческие способности человека [Зиятдинов, 2004, с. 16]: «Только труд и учеба что-то дадут в жизни» (мать); «Тьв взрослая, умная, способная, делай то, что нужно. И все у тебя встанет на место и будет хорошо, и получишь удовлетворение своей учебой. Работай и оиенят тебя» (мать).

2. Образование как ценность. Ценность образования воплощается в эпистолярии как представление «о значимости образования и отношение к нему как цели и средству» [Пермякова, 1999, с. 165] субъекта. Обозначенная доминанта реализуется в тексте с помощью лексем (и их сочетаний), интегрированных семами 'знание', ‘образование': «учеба», «обучение», «аспирантура», «университет», «ум» и др.: «[...] начинается большая полоса жизни и период приложения своих сил, знаний устройства своей жизни. Нужно настраиваться на научную работу, на аспирантуру. Не вешать нос, борьба продолжается, жизнь только начинается. 
Думаю, что у тебя хватит ума и выдержки, твердости довести дело до конца с достоинством и честью» (отеи); «У тебя, Наташа, последний год учебы. А там начнется творческая самостоятельная, дай бог, счастливая жизнью. Поэтому нужно быть сильной и в знаниях и здоровья иметь и тогда всё по плечу» (отеи).

Рассуждая об инструментальном характере ценности образования как средстве удовлетворения некоторых потребностей и целей, Т. В. Пермякова [Пермякова, 1999, c. 165] не исключает возможности обретения образованием статуса терминальной ценности. Полагаем, что на уровне рассматриваемой семьи речь идет о подобного рода статусно-престижной ценности образования, ибо для членов данной семьи актуален интерес к образованию как самоценности. Образование как социокультурная ценность реализуется в образовательной деятельности (учении) и образовательном знании, представленном как знание гуманитарное, профессиональное, повседневное: «Сейчас очень требовательные люди. К нам приезжают студенты и меняются какие были когда-то и сейчас намного выше. И культурой в отношениях с людьми да серьезностью кжизни и работе» (отеи); «Читаю книгу князя Трубецкова. Наслаждаюсь, образованный, культурный, приятный человек описывает предреволюционное время и революиию» (мать); «Умный серьезный хорошо играет в шахматыл» (отеи о соседском мальчике).

3. Рачительность (разумная бережливость) как ценность включает систему действий, приводящую к умеренному расходу. Включаясь в аксиосферу рассматриваемой семьи, бережливость расценивается как важное качество личности, связанное со способностью соблюдать разумную меру в расходовании ресурсов, прежде всего денежных. Представленная доминанта воплощается в тексте письма посредством ключевых слов: «экономия», «экономный», «деньги», «дорого», «дороговизна» и др.: «Mbl в этом году к вам не собираемся. В это лето все у нас побывали, поэтому нет необходимости расходовать средства на поездки без причин» (отеи); «По делам практическим. Нужно найти подругу по комнате [в общежитии - прим. авт.]. Одной жить дорого и скучно» (отеи).

4. Самоконтроль (самодисциплина) занимает одну из основных позиций в семейной аксиосфере. Самоконтроль представляется как рациональный взгляд человека на его поступки, состояние, мотивы и проявляется в способности человека контролировать психологические реакции на внешние раздражители. Обозначенная доминанта реализуется с помощью аксиологем-репрезентантов внутреннего мира человека «достоинство», «благоразумие», «терпимость», «упорство» и др.: «Будь благоразумна к себе. Если тебя кто-то не ценит, махни на его или их. Ть умница смелая, еще научишься властвовать собой (ну кончатся у тебя стычки с людьми) и станешь дипломатичнее» (мать); «Наташа, тебе надо взять себя в руки и по-взрослому вести себя (меньше раздражительности), а то войдет в привычку и будет нехоромей чертой характера. Нужно уметь, а это нетрудно, неприятных недоброжелательных людей обходить молчанием не допуская к себе, то есть не вступая в скандал, лучше их не замечать. Лучше сердиться молча, чем ругаться. Это унижает человека. Как Пушкин сказал, умейте властовать собой» (мать); «Хотелось бы, чтобы ты избавлялась от нервозности, чтобы в твоем характере вырабатывалась спокойная уверенность, исчезла раздражительность и особенно грубость» (отеи); «Не вмешивайся в конфликты. Будь нейтральна» (отеи). 
Эпистолярный материал позволяет проследить динамику социальнооценочного содержания общественного сознания, которая представляется в двух временных пластах - советском (70-е гг.- первая половина 80-х гг.) и перестроечном (вторая половина 80-х гг.-90-е гг.). Период «перестройки» сопровождается масштабными переменами в идеологии, экономической и политической жизни. Создание новой экономики, основанной на рыночных отношениях, приватизация большинства государственных предприятий, развитие частной собственности сопровождается резким падением уровня жизни. Обнаруживаемый ценностный конфликт взрослого поколения, к которому принадлежат авторы писем, и молодого поколения усугубляется общей аномией общества. Обозначенный конфликт затрагивает мировоззренческие основы дальнейшего общественного развития. Исследуемый эпистолярий отражает происходящие в обществе изменения, относительно которых авторы занимают ценностную позицию: «Как жить, деньги задерживают. Да идут у нас сокращения. Продают наши разрезы, вот ГРЭСС продали американцам. Хозяин новый сокращает рабочих, хотя платит два раза в месяи» (мать); «Жизнь плохая, хоть хвалят. [...] ко мне ходят дети от 3 лет до 14 просят милостыни. Раньше при коммунистах все дети были пристроенные в детсаде и в школе» (мать); "По телевизору нечего смотреть, кроме СантаБарбары (герои надоели мне особенно Иден и Круз [...] Кошмар и эта еще война в Чечне! Господи, помоги России. Когда будут умные правители у нас» (мать).

\section{IV. Заключение}

Таким образом, представленный в исследовании аксиологический анализ семейного эпистолярия являет собой новый взгляд на ЕПР рядового носителя языка. Аксиологический подход к ЕПР имеет в своей основе рассмотрение текстов ЕПР как знаковых репрезентаций естественной письменной речевой деятельности человека, не связанной с присутствием внешних субъектов оценки, а потому характеризующейся естественностью, возможностью выражения личностного начала, как проявление последнего, ценностным отношением к миру и самому себе. Подобного рода исследования призваны устранить лакуну между аксиологией и теорией ЕПР, между философско-эстетической трактовкой понятия ценности и изучением ценностной структуры естественной письменно-речевой деятельности рядового носителя языка в ее жанрово-текстовом воплощении. Аксиологический потенциал жанров ЕПР представляется неодинаковым. В большей степени аксиологическая составляющая письменной речевой деятельности проявляется в жанрах, где значим оценочно-рефлексирующий компонент. Среди них мемуары, личные дневники, частные письма, в которых оценочная реакция на события, субъектов внешнего и внутреннего мира (последнее в большей мере характеризует дневник) оказывается зачастую самоцелью. Подобного рода реакция на некие события внешней и внутренней жизни в жанре родительского письма детерминирована его дидактической интенцией. Демонстрация этих реакций осуществляется с ориентацией на адресата, в отношении которого адресант занимает назидательную позицию, призванную обозначить и упорядочить ценностные предпочтения формирующегося человека. 


\section{СПИСОК ЛИТЕРАТУРЫ}

Арутюнова, Н. Д. Язык и мир человека / Н. Д. Арутюнова.- Москва: Языки русской культуры, 1999.- 896 с.

Байкулова, А.Н. Речевое общение в семье: дис. ... канд. филол. наук / А. Н. Байкулова.- Саратов, 2006.- 290 с.

Белов, В. И. Лад. Очерки народной эстетики / В. И. Белов.- Москва: Институт русской цивилизации, 2013.- 512 с.

Вознесенская, И.М. Дневник: особенности семантической структуры и речевой организации / И. М. Вознесенская // Мир русского слова.- 2006.- № 3.- С. 41-48.

Голев, Н.Д. Современная ментально-языковая ситуация в аспекте взаимоотношений ее лингвистического и лингводидактического аспектов / Н.Д.Голев // Естественная письменная русская речь: исследовательский и образовательный аспекты: Матер. конференции.- Барнаул: Изд-во Алт. ун-та, 2003.- Ч. 2.- С. 178-192.

Занадворова, А. В. Функционирование русского языка в малых социальных группах: Речевое общение в семье: дис. ... канд. филол. наук / А. В. Занадворова.Москва, 2001.- 173 с.

Зиятдинов, Р. Н. Отношение к труду как ценности: автореферат дис. ... канд. философ. наук / Р. Н. Зиятдинов.- Пермь, 2004.- 20 с.

Зырянова, Е. Г. Частная записка как жанр естественной письменной русской речи: дис. ... канд. филол. наук / Е. Г. Зырянова.- Кемерово, 2009.- 197 с.

Кабанова, Т. Н. Эпистолярный текст частной переписки в аспекте теории речевого общения: на материале рукописных и опубликованных текстов XX в.: автореф. дис. ... канд. филол. наук / Т. Н. Кабанова.- Челябинск, 2004.- 24 с.

Крючкина, Н. Ю. Личное письмо как жанр естественной письменной речи: гендерный аспект / Н. Ю. Крючкина, Т. Г. Рабенко // Естественная письменная русская речь: исследовательский и образовательный аспекты: Сб. научных трудов.- Кемерово: КемГУ, 2016.- С. 175-180.

Лебедева, Н. Б. Естественная письменная русская речь как проявление повседневной народной культуры / Н. Б. Лебедева // Антропотекст-1: Сб. статей.Томск: Изд-во Том. ун-та, 2006.- С. 295-303.

Лебедева, Н. Б. Жанры естественной письменной речи: Студенческое граффити, маргинальные страницы тетрадей, частная записка / Н. Б. Лебедева, Е. Г. Зырянова, Н. Ю. Плаксина, Н. И. Тюкаева.- Москва: URSS, 2011.- 256 с.

Лебедева, Н. Б. Наивный автор как письменно-речевая личность: жанровый аспект: монография / Н. Б. Лебедева, Е. А. Корюкина.- Кемерово: КемГУ, 2013.- 179 с.

Лебедева, Н. Б. Ценностные доминанты народных мемуаров / Т. Г. Рабенко // Аксиологические аспекты современных филологических исследований: тез. докл. Междунар. науч. конф.- Екатеринбург: ИД «Ажур», 2019.-С. 252-253.

Новиков, А. И. Семантика текста и её формализация / А. И. Новиков.Москва: Наука, 1983.-215 с. 
Пермякова, Т. В. Образование как ценность: дис. ... канд. социолог. наук / Т. В. Пермякова.-Екатеринбург, 1999.- 165 с.

Рабенко, Т.Г. Жанры естественной письменной русской речи в вариантологическом аспекте: дис. ... д-ра филол. наук / Т. Г. Рабенко.-Кемерово, 2018a. -356 c.

Рабенко, Т.Г. Русский речевой жанр в парадигме лингвистической вариантологии (на материале речевого жанра личный дневник): монография / Т. Г. Рабенко.-Кемерово: КемГУ, 2018b.-171 c.

Рабенко, Т. Г. Ценностные доминанты дневникового жанра / Т. Г. Рабенко // Аксиологические аспекты современных филологических исследований: тез. докл. Междунар. науч. конф.- Екатеринбург: ИД «Ажур», 2019.-С. 257-259.

Рабенко, Т. Г. Инвариантные и вариантные признаки жанров естественной письменной речи (на материале жанров «личный дневник», «личное письмо», «личная записка») / Т. Г. Рабенко // Жанры речи.-2020.- № 1 (25).- С. 6-14.

Русская разговорная речь / Отв. ред. Е. А. Земская.- Москва: Наука, 1973.$485 \mathrm{c}$.

Сахарный, Л. В. Набор ключевых слов как тип текста / Л. В. Сахарный, А. С. Штерн // Лексические аспекты в системе профессионально-ориентированного обучения иноязычной речевой деятельности.-Пермь: Пермский политехнический ун-т, 1988.- С. 34-51.

Сковородников, А.П. Ключевые слова / А.П.Сковородников // Стилистический энциклопедический словарь русского языка / под ред. М. Н. Кожиной.- Москва: Флинта: Наука, 2011.-С. 153-157.

Сухотерина, Т. П. Поздравление как гипержанр естественной письменной русской речи: дис. ... канд. филол. наук / Т. П. Сухотерина.-Барнаул, 2007.-252 с.

Тороп, П. Тотальный перевод / П. Тороп.- Тарту: Научный поиск, 1995.$256 \mathrm{c}$.

Тюкаева, Н. И. Граффити как жанр естественной письменной русской речи: автореф. дис. ... канд. филол. наук / Н. И. Тюкаева.-Барнаул, 2005.-18 с.

Ухтомский, А. А. Доминанта / А. А. Ухтомский.-Санкт-Петербург: Питер, 2002. $-448 \mathrm{c}$.

Формановская, Н.И. Речевой этикет и культура общения / Н. И. Формановская.- Москва: Высшая школа.-1989.- 156 с.

Чайковский, Р.P. Язык в семье как разновидность социолекта / Р. Р. Чайковский // Вариативность как свойство языковой системы: Сб. статей.Москва: Наука, 1982.- Ч. 2.- С. 74-81.

Черняк, В. Д. Текстовые проекции глагольных синонимических рядов / В. Д. Черняк // Проблема исследования слова в художественном тексте.- Ленинград: Наука, 1990.- С. 27-38.

Rokeach, M. Value Survey / M. Rokeach.-Sunnyvale, 1967.-216 p. 


\section{REFERENCES:}

Arutyunova, N. D. YAzyk i mir cheloveka / N. D. Arutyunova.-Moskva: YAzyki russkoj kul'tury, 1999.-896 s.

Bajkulova, A. N. Rechevoe obshchenie v sem'e: dis. ... kand. filol. nauk / A. N. Bajkulova.-Saratov, 2006.-290 s.

Belov, V. I. Lad. Ocherki narodnoj estetiki / V. I. Belov.-Moskva: Institut russkoj civilizacii, 2013.- $512 \mathrm{~s}$.

Chajkovskij, R. R. YAzyk v sem'e kak raznovidnost' sociolekta / R.R. CHajkovskij // Variativnost' kak svojstvo yazykovoj sistemy: Sb. statej.-Moskva: Nauka, 1982.- CH. 2.-S. 74-81.

Chernyak, V.D. Tekstovye proekcii glagol'nyh sinonimicheskih ryadov / V.D. CHernyak // Problema issledovaniya slova v hudozhestvennom tekste.- Leningrad: Nauka, 1990.-S. 27-38.

Formanovskaya, N.I. Rechevoj etiket i kul'tura obshcheniya / N. I. Formanovskaya.-Moskva: Vysshaya shkola.-1989.-156 s.

Golev, N. D. Sovremennaya mental'no-yazykovaya situaciya $\mathrm{v}$ aspekte vzaimootnoshenij ee lingvisticheskogo i lingvodidakticheskogo aspektov / N.D.Golev // Estestvennaya pis'mennaya russkaya rech': issledovatel'skij i obrazovatel'nyj aspekty: Mater. konferencii.- Barnaul: Izd-vo Alt. un-ta, 2003.CH. 2.-S. 178-192.

Kabanova, T. N. Epistolyarnyj tekst chastnoj perepiski v aspekte teorii rechevogo obshcheniya: na materiale rukopisnyh i opublikovannyh tekstov XX v.: avtoref. dis. ... kand. filolog. nauk / T. N. Kabanova.-CHelyabinsk, 2004.-24 s.

Kryuchkina, N. YU. Lichnoe pis'mo kak zhanr estestvennoj pis'mennoj rechi: gendernyj aspect / N.YU., Kryuchkina, T. G. Rabenko // Estestvennaya pis'mennaya russkaya rech': issledovatel'skij i obrazovatel'nyj aspekty: Sb. nauchnyh trudov.Kemerovo: KemGU, 2016.-S. 175-180.

Lebedeva, N. B. Estestvennaya pis'mennaya russkaya rech' kak proyavlenie povsednevnoj narodnoj kul'tury / N. B. Lebedeva // Antropotekst-1: Sb. statej.- Tomsk: Izd-vo Tom. un-ta, 2006.- S. 295-303.

Lebedeva, N. B. ZHanry estestvennoj pis'mennoj rechi: Studencheskoe graffiti, marginal'nye stranicy tetradej, chastnaya zapiska / N. B. Lebedeva, E. G. Zyryanova, N.YU. Plaksina, N. I. Tyukaeva.-Moskva: URSS, 2011.-256 s.

Lebedeva, N. B. Naivnyj avtor kak pis'menno-rechevaya lichnost': zhanrovyj aspekt: monografiya / N. B. Lebedeva, E. A. Koryukina.- Kemerovo: KemGU, 2013.$179 \mathrm{~s}$.

Lebedeva, N. B. Cennostnye dominanty narodnyh memuarov / T. G. Rabenko // Aksiologicheskie aspekty sovremennyh filologicheskih issledovanij: tez. dokl. Mezhdunar. nauch. konf.-Ekaterinburg: ID «Azhur», 2019.-S. 252-253.

Permyakova, T. V. Obrazovanie kak cennost': dis. ... kand. sociology. nauk / T. V. Permyakova.- Ekaterinburg, 1999.-165 s. 
Rabenko, T.G. Zhanry estestvennoj pis'mennoj russkoj rechi v variantologicheskom aspekte: dis. ... d-ra filol. nauk / T. G. Rabenko.- Kemerovo, 2018a.-356 s.

Rabenko, T. G. Russkij rechevoj zhanr v paradigme lingvisticheskoj variantologii (na materiale rechevogo zhanra lichnyj dnevnik): monografiya / T.G. Rabenko.Kemerovo: KemGU, 2018b.-171 s.

Rabenko, T. G. Cennostnye dominanty dnevnikovogo zhanra / T. G. Rabenko // Aksiologicheskie aspekty sovremennyh filologicheskih issledovanij: tez. dokl. Mezhdunar. nauch. konf.-Ekaterinburg: ID «Azhur», 2019.-S. 257-259.

Rabenko, T. G. Invariantnye i variantnye priznaki zhanrov estestvennoj pis'mennoj rechi (na materiale zhanrov «lichnyj dnevnik», «lichnoe pis'mo», «lichnaya zapiska») / T. G. Rabenko // ZHanry rechi.-2020.- № 1 (25).-S. 6-14.

Russkaya razgovornaya rech' / Otv. red. E. A. Zemskaya.- Moskva: Nauka, 1973. $-485 \mathrm{~s}$.

Saharnyj, L. V. Nabor klyuchevyh slov kak tip teksta / L. V. Saharnyj, A.S. SHtern // Leksicheskie aspekty v sisteme professional'no-orientirovannogo obucheniya inoyazychnoj rechevoj deyatel'nosti.-Perm': Permskij politekhnicheskij un-t, 1988.S. 34-51.

Skovorodnikov, A. P. Klyuchevye slova / A. P. Skovorodnikov // Stilisticheskij enciklopedicheskij slovar' russkogo yazyka / pod red. M. N. Kozhinoj.--Moskva: Flinta: Nauka, 2011.-S. 153-157.

Suhoterina, T. P. Pozdravlenie kak giperzhanr estestvennoj pis'mennoj russkoj rechi: dis. ... kand. filol. nauk / T. P. Suhoterina.-Barnaul, 2007.-252 s.

Torop, P. Total'nyj perevod / P. Torop.- Tartu: Nauchnyj poisk, 1995.-256 s.

Tyukaeva, N. I. Graffiti kak zhanr estestvennoj pis'mennoj russkoj rechi: avtoreferat dis. ... kand. filol. nauk / N. I. Tyukaeva.-Barnaul, 2005.-18 s. $448 \mathrm{~s}$.

Uhtomskij, A. A. Dominanta / A. A. Uhtomskij.-Sankt-Peterburg: Piter, 2002.-

Voznesenskaya, I. M. Dnevnik: osobennosti semanticheskoj struktury i rechevoj organizacii / I. M. Voznesenskaya // Mir russkogo slova.-2006.- № 3.- S. 41-48.

Zanadvorova, A. V. Funkcionirovanie russkogo yazyka v malyh social'nyh gruppah: Rechevoe obshchenie v sem'e: dis. ... kand. filol. nauk / A. V. Zanadvorova.-Moskva, 2001.- $173 \mathrm{~s}$.

Ziyatdinov, R. N. Otnoshenie k trudu kak cennosti: avtoreferat dis. ... kand. filosof. nauk / R. N. Ziyatdinov.-Perm', 2004.-20 s.

Zyryanova, E. G. CHastnaya zapiska kak zhanr estestvennoj pis'mennoj russkoj rechi: dis. ... kand. filol. nauk / E. G. Zyryanova.-Kemerovo, 2009.-197 s.

Rokeach, M. Value Survey / M. Rokeach.-Sunnyvale, 1967.-216 s. 